\title{
A note on ryanodine receptor gene (ryr 1 ) occurrence in the anserine genome
}

\author{
P. Gronek ${ }^{1}$, Dobrawa Napierala ${ }^{2}$, A. Plawski ${ }^{2}$, A. Rosiński ${ }^{3,4}$, \\ R. Słomski ${ }^{2,5}$ and T. Banasiewicz ${ }^{6}$
}
'Department of Pig Breeding and Production. August Cieszkowski Agricultural University Wolyńska 33, 60-637 Poznań, Poland
2 Department of Human Genetics, Polish Academy of Sciences
Strzeszyńska 32, 60-479 Poznań, Poland
${ }^{3}$ Department of Poultry Breeding and Production, August Cieszkowski Agricultural University
Wolyniska 33, 60-637 Poznań, Poland
${ }^{4}$ Research Institute of Animal Production, Koluda Wielka Experimental Station 88-160 Janikowo, Poland
${ }^{5}$ Department of Biochemistry and Biotechnology, August Cieszkowski Agricultural University
Wolyniska 35, 60-637 Poznań, Poland
${ }^{6}$ III Chair and Department of Surgery, K. Marcinkowski University of Medical Sciences Przybyszewskiego 49, 60-355 Poznań, Poland

(Received 10 August 1998; accepted 19 March 1999)

\begin{abstract}
The PCR products of the ryrl gene amplified from anserine genomic DNA were analysed. We used the polymerase chain reaction-restriction fragment length polymorphism (PCR-RFLP) method to investigate the anserine ryanodine receptor $(r y r l)$ gene. The anserine fragment of the ryr $I$ gene was the same size as exon 17 of the porcine ryrl gene.
\end{abstract}

KEY WORDS: ryanodine receptor gene, goose, PCR-RFLP

\section{INTRODUCTION}

The typical avian karyotype consists of a few distinguishable macrochromosomes and a high number of very small microchromosomes (Ladjali et al., 1993; Rodionov, 1996). The presence of numerous cytogenetically indistinguishable mi- 
crochromosomes complicates the mapping of genes and other DNA fragments and integrating the genetic maps of the karyotype.

Henschel and Louw (1978) reported malignant hyperthermia (MH) in birds. $\mathrm{MH}$ is linked to mutations in the ryanodine receptor which is a calcium release channel protein on the intracellular $\mathrm{Ca}^{2+}$-store in skeletal muscle. The human and rabbit ryanodine receptor genes ( $R Y R I)$ have been mapped (MacKanzie et al., 1990 ) and sequenced (Zorzato et al., 1990; Phillips et al., 1996), and the porcine ryrl gene has been localised (Davies et al., 1988); cDNAs have been cloned (Fujii et al., 1991). The RYRI gene is composed of 106 exons, of which two are alternatively spliced (Phillips et al., 1996). In studies on the genetic basis of malignant hyperthermia $(\mathrm{MH})$, the a $1843 \mathrm{C} \rightarrow \mathrm{T}$ mutation in the porcine ryrl gene corresponding to an Arg ${ }^{615}$ to Cys alteration has been identified (Fujii et al., 1991) and linked to malignant hyperthermia $(\mathrm{MH})$ with a lod score of 102 for $\theta$ max. $=0.0$ (Otsu et al., 1991). The corresponding human RYRI mutation, $\operatorname{Arg}^{\text {(114 }}$ to Cys, was found to be expressed in about $2 \%$ of MH families (Gillard et al., 1992).

The primary aim of this study was to determine whether the $r y r l$ gene occurs in the anserine genome.

\section{MATERIAL AND METHODS}

\section{Animals}

The research was performed on genomic anserine DNA: e.g. White Italian goose (Anser anser) $(\mathrm{n}=20)$, White Italian goose, strain WD3 (Anser anser) $(\mathrm{n}=20)$, Garbonosa goose (Anser anser $x$ Anser cygnoides) $(\mathrm{n}=20)$ originating from Poland, and Polish Large White swine $(\mathrm{n}=20)$. The anserine blood samples were taken from the vena cutanea ulnaris.

\section{Methods}

In this study, consensus primers were designed based on the porcine ryanodine receptor (ryrl) cDNA sequences where natural polymorphism occurs, and used to amplify a fragment of exon 17 of the anserine ryanodine receptor gene. The PCR reactions were performed in a $25 \mathrm{ml}$ mix containing: $0.1 \mathrm{mg}$ genomic DNA, 10 pmol primer RYR1F 5'-Cy5-GTTCCCTGTGTGTGTGCAATGGTG-3', which corresponds to porcine ryrl cDNA nucleotides 1811 to 1834 , and 10 pmol RYR1R 5'(GCCAGGGAGCAAGTTCTCAGTAAT-3') in which the last 24 nucleotides are complementary to $r y r l$ cDNA nucleotides 1861 to 1884 , dNTPs fc $300 \mu \mathrm{M}, 2.5 \mu 1$ $10 \times$ PCR buffer and $0.5 \mathrm{U}$ Taq DNA Polymerase. Thermocycling was performed by initial denaturation for $5 \mathrm{~min}$ at $94^{\circ} \mathrm{C}, 30$ cycles of $45 \mathrm{~s}$ denaturation at $92^{\circ} \mathrm{C}, 45$ 
$\mathrm{s}$ annealing at $55^{\circ} \mathrm{C}, 60 \mathrm{~s}$ hybridisation at $70^{\circ} \mathrm{C}$ and $7 \mathrm{~min}$ final extension at $70^{\circ} \mathrm{C}$. For automatic analysis of PCR products on ALFexpress ${ }^{\mathrm{TM}}$ Sequencer (Pharmacia LKB) primers were labelled at the $5^{\prime} \mathrm{end}$ with $\mathrm{Cy} 5$. Electrophoresis was performed on $10 \%$ polyacrylamide gel at $30^{\circ} \mathrm{C}$ using the following conditions: $25 \mathrm{~W}, 60 \mathrm{~mA}$, $200 \mathrm{~V}$. Allele size was quantified using Fragment Manager V 1.2 ${ }^{\oplus}$ (Pharmacia Biotech) software. Because the $1843 \mathrm{C} \rightarrow \mathrm{T}$ mutation changes, a HinP1 site to a HgiAl site the PCR-RFLP method was used. The PCR-RFLP for detection of mutant alleles was performed using $\mathrm{Hin} \mathrm{P} 1$ enzyme $(10,000 \mathrm{U} / \mathrm{ml}$, Biolabs $)$ as follows: 10 $\mathrm{ml}$ of the amplified products were digested with $\operatorname{HinP} 1$ ( 10 units) for $3 \mathrm{~h}$ at $37^{\circ} \mathrm{C}$ in the appropriate buffer containing BSA.

\section{RESULTS AND DISCUSSION}

The goose PCR product was of the same size as the porcine one (74 bp) (Figure 1). In the analyzed geese material, no individuals with substitution of $\mathrm{T}$ for $\mathrm{C}$ at nucle-

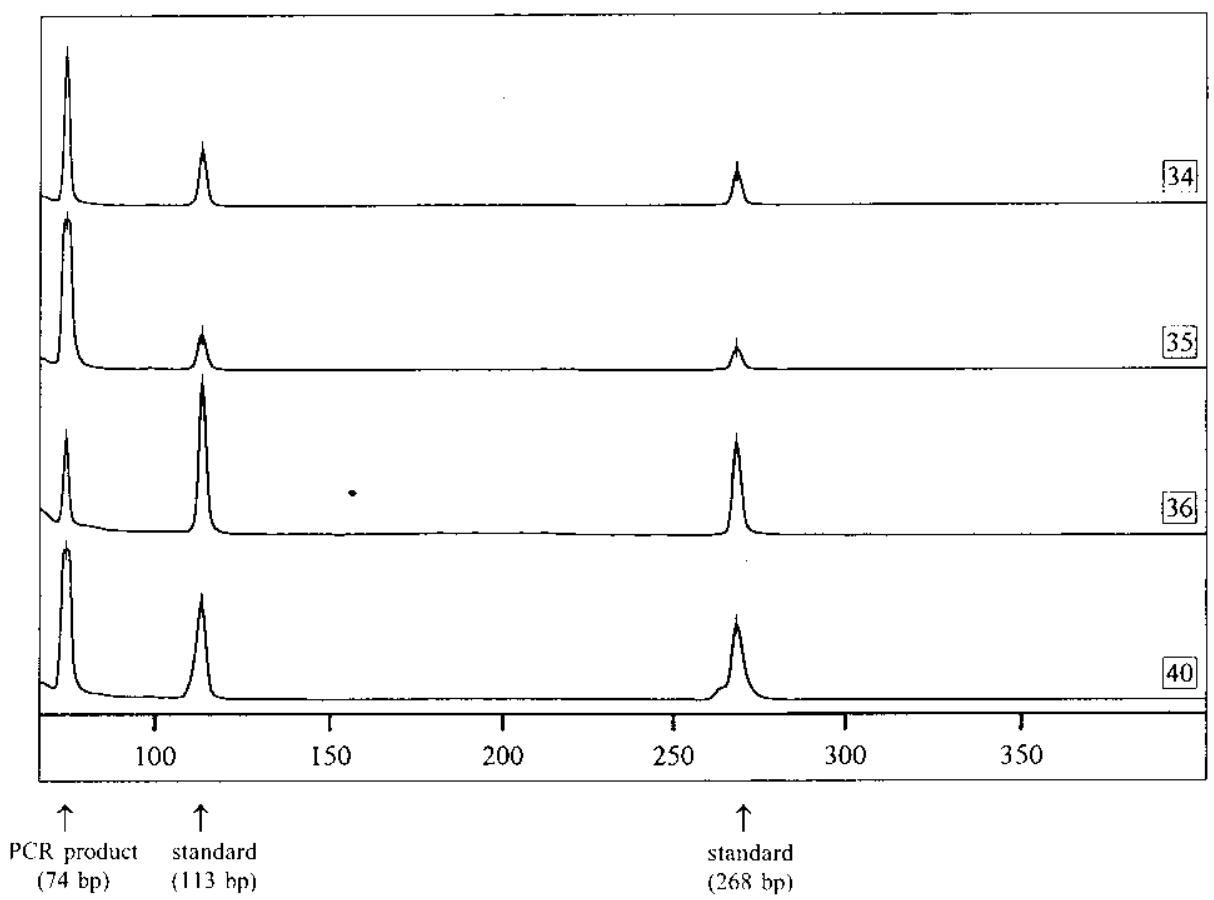

Figure 1. The analysed fragment of the $r y r l$ gene amplified with oligonucleotides based on porcine cDNA sequence. Line 34 White Italian goose, WD3 strain (Anser anser); line 35 White Italian goose (Anser anser); line 36 Garbanosa goose (Anser anser $x$ Anser cygnoides): line 40 porcine 
otide 1843 were detected. Nonetheless, since the study involved a relatively small population, it is difficult to draw any statistical conclusions. However, only $\mathrm{C} / \mathrm{C}$ genotypes were observed.

\section{CONCLUSIONS}

This analysis shows that PCR based on primers for a known porcine cDNA sequence may be suitable for the homologous gene sequence of other genomes. Molecular techniques applied in this study permitted the analysis of a fragment of the $r y r l$ gene in the goose. It seems that the gradual mapping of the goose genome should make the identification of genes responsible for genetic defects feasible. Creation of marker maps of goose genomes may help in explaining their evolution.

This study may be a model for other genes, especially for those species which, despite being closely related to one another, display cytogenetic differences. It seems that localization and identification of animal disease genes are the most important aspects of animal gene mapping.

\section{ACKNOWLEDGMENTS}

We thank Kasia Dziechciowska for her technical assistance on ALFexpress ${ }^{\mathrm{TM}}$.

\section{REFERENCES}

Davies W., Harbitz I., Fries R., Stranzinger G., Hauge J., 1988. Porcine malignant hyperthermia carrier detection and chromosomal assignment using linkage probe. Anim. Genet. 19, 203-212

Fujii J., Otsu K., Zorzato F., De Leon S., Khanna V.K., Weiler J.E., O'Brien P.J., MacLennan D.H., 1991. Identification of a point mutation in porcine ryanodine receptor associated with malignant hyperthermia. Science 253,448-451

Gillard E.F., Otsu K., Fujii J., Duff C.L., De Leon S., Khanna V.K., Britt B.A., Worton R.G., MacLennan D.H., 1992. Polymorphism and deduced amino acid substitutions and the coding sequence of the ryanodine receptor (RYR 1 ) gene in the individuals with malignant hyperthermia. Genomics 13, 1247-1254

Henschel J.R., Louw G.N., 1978. Capture stress, metabolic acidosis and hyperthermia in birds. S. Afr. J. Sci. 74, 305-306

Ladjali K., Bitgood J.J., Schoffner R.N., Ponce de Leon F.A., 1993. International Committee for Standarization of the Avian Karyotype (ICSAK). In: 8th North American Collegium on Domestic Animals Cytogenetics. Guelph, Ontario (Canada)

MacKanzie A.E., Korneluk R.G., Zorzato F, Fujii J., Phillips M., Iles D., Wieringa B., Leblond S., Bailly J., Willard H.F., Duff C., Worton R.G., MacLennan D.H., 1990. The human ryanodine receptor gene: Its mapping to $19 \mathrm{q} 13.1$, placement in a chromosome 19 linkage group, and exclusion as the gene causing myotonic dystrophy. Amer. J. Hum. Genet. 46, 1082-1089 
Otsu K., Khanna V.K., Archibald A.L., MacLennan D.H., 1991. Cosegregation of porcine malignant hyperthermia and a probable causal mutation in the skeletal muscle ryanodine receptor gene in backcross families. Genomics 11, 744-750

Phillips M.S., Fujii J., Khanna V.K., Deleon S., Yokobata K., De Jong P.J., MacLennan D.H., 1996. The structural organization of the human skeletal muscle ryanodine receptor (RYR1) gene. Genomics 34, 24-41

Rodionov A.V., 1996. Micro versus macro: a review of structure and function of avian micro- and macrochromosomes. Rus. J. Genet. 32, 517-527

Zorzato F., Fujii J., Otsu K., Phillips M., Green N.N., Lai F.A., Meissner G., MacLennan D.H., 1990. Molecular cloning of cDNA encoding human and rabbit forms of the $\mathrm{Ca}^{2+}$ release channel (ryanodine receptor) of skeletal muscle sarcoplasmic reticulum. J. Biol. Chem. 265, 2244-2256

\section{STRESZCZENIE}

\section{Gen receptora ryanodiny występuje u gęsi}

Badania molekularne przeprowadzono na DNA gęsi. W oparciu o startery skonstruowane na podstawie znanej sekwencji cDNA genu ryrl świni przeprowadzono reakcję amplifikacji oraz wykonano analizę PCR-RFLP. Otrzymane wyniki pozwalają sądzić, że gen receptora ryanodiny najprawdopodobniej występuje w genomie ptaków, czego dotychczas nie stwierdzono. Jednoznacznym potwierdzeniem tych pierwszych obserwacji będzie na dalszym etapie badań poznanie sekwencji i określenie stopnia homologii pomiędzy gatunkami. W badanej grupie zwierząt nie zaobserwowano mutacji $1843 \mathrm{C} \rightarrow \mathrm{T}$. 